\title{
Interest Free Banking in Ethiopia: Prospects and Challenges
}

\section{Suadiq Mehammed Hailu* Ibrahim Bushera*}

Received: 23.01 .2020

Accepted: 25.06.2020

DOI: $10.25272 /$ ijisef.678972

Type: Research Article

\begin{abstract}
Ethiopia has a substantial number of Muslims estimated more than 38 million. Ethiopia adopted Islamic banking through interest-free banking window scheme in 2011 and Full-fledged interest-free banking by the end of 2019. This study aims to investigate the prospects and challenges of the newly adopted full-fledged interest-free banking system. For these purposes, several secondary data collected and analyzed descriptively. In addition mainstream media contents are analyzed so as understand public reaction and perception. The result indicates that Islamic finance has a notable opportunity in Ethiopia. Unbanked huge customers, lofty demand, the profitability of IFB windows indicate the prospects. While negative perception toward Islamic finance, legal framework challenges like the exclusiveness of banking business activity, limitation on investment of banks, tax system and unavailability of controlling mechanism last but not least lack of experts and skilled resource are identified as the main impediments of the sector. Therefore, it is recommended to the government of Ethiopia to make accommodative adjustments on the legal frameworks to resolve the shortcomings and for educational institutions to provide programs, seminars, and training in the area of Islamic finance in order to produce experts that serve the sector.
\end{abstract}

Keywords: Ethiopia, Islamic finance, interest-free window, full-fledged, legal framework

Jel Codes: F65, G2, G21

\footnotetext{
* Çukurova University, PhD Candidate in Finance, Adana. Turkey. suadiq1434@gmail.com, ORCID: https://orcid.org/0000-0003-3270-1357

** Ibn Haldun University, Assistant Researcher in Faculty of Business and Economics. Istanbul, Turkey. ibrahim.bushera@ibnhaldun.edu.tr, ORCID: https://orcid.org/0000-0001-6762-4887
} 


\section{Introduction}

It is vivid that, the reason for the emergence of modern Islamic finance is to provide alternative Sharia-compliant financial services and products for those who are not able to access conventional financial services due to religious rationale. Gait \& Worthington (2007:1) defines Islamic finance as "financial institutions and products designed to comply with the central tenets of Sharia (or Islamic law) - is one of the most rapidly growing segments of the global finance industry". According to Franzoni and Allali (2018), quite apart from the conventional finance, Islamic finance is built upon five pillars which are the indispensable measurements of religious validity (Sharia Compliance) of any financial activity performed under the umbrella of Islamic finance. These fundamental pillars are prohibition of Riba( interest), ban on speculative elements in financial contracts(Gharar), Prohibition of gambling (mayser), ban on the use of trade and investment involving any element of prohibited asset or activity (Haram), profit and loss sharing principle and the imperative to have real assets underlying any given financial transaction.

The history of Islamic finance dates back to the era of Prophet Muhammad (Mohamad, et al., 2013). From the rise of Islam until the 12th century, there were different Sharia-compliant financial instruments utilized in the Muslim World. Among these financial instruments accepting deposit, Money transfer, bankers called sarrafeen or sayarifah, Promissory notes (reqaah al-sayarifah), bills of exchange (suftaja), cheque (sakk) and treasury (Baytal-Mal) were common (Chachi, 2005; Mohamad, et al., 2013; Alharbi, 2015). The decline of Muslims civilization, mainly due to gradual deviation from sharia, extravagance, lack of wellestablished organization, political breakdown, the rise of different Islamic sects and different wars shifted the balance of trade from Muslims to Europeans. Consequently, Muslims also lost their technological and economic advancement. Henceforth, the financial system of all Muslim countries went astray from Sharia-compliance resulting in the adaptation of the western-based conventional financial system (Chachi, 2005).

By the mid-19th Century, almost all Muslim countries adopted the interest-based western financial system (Chachi, 2005). On the subject of adapting conventional financial system Muslim scholars' opinion fall into three groups. Scholars in the first group opined accessing conventional financial services is halal (permitted). Contrary to this, the second group of scholars argued accessing conventional finance is Haram (prohibited) but, it is also important. The third group argued that accessing conventional finance is necessary though riba (interest) is undoubtedly prohibited (haram). The advocator of the third argument suggested that Islamic sharia has several types of contracts that can be applied in banking business without interest and it is also possible to establish an interest-free banking system (Nasser 1996, as cited in Alharabi, 2015).

Finally, in the 1940s, the idea of establishing an interest-free banking system gained momentum in the theoretical arena, a milestone to modern Islamic finance (Alharabi, 2015). The first attempt to establish an interest-free bank was commenced in the rural area of Pakistan 
in the 1950s. On 25th July 1963, Mit- Ghamar Islamic saving Bank (MGISB) was established in Egypt by El-Naggar (Chachi, 2005). In addition to the establishment of Islamic banks, in the 1970s the modern practice of Islamic insurance (Takaful) as well emerged. The first Islamic insurance company was established in Sudan in 1979. Following the success of this company, the practice of Takaful expanded through Muslim and Non-Muslim countries (Hussain and Pasha, 2011). The Islamic model of microfinance project also started in Sudan in the late 1980s (Mollah and Uddin, 2013).

Islamic finance expanded throughout the Middle East aggressively, and currently, it is stretching out in all parts of the world. According to the Global Islamic Finance Report (GIFR, 2019), The total capital of Islamic finance has reached US\$2.6 trillion at the end of 2018 with a $6.58 \%$ annual growth rate. Indonesia, Malaysia, Iran, Saudi Arabia, Sudan, Brunei Darussalam, UAE, Bangladesh, Kuwait and Pakistan are the top 10 leading countries in Islamic finance Industry. Based on the total share from the global Islamic finance asset, the leading sectors in 2018 are Islamic banking, Sukuk, Islamic funds and Takaful with 71.7\%, 24.2\%, 2.8\% and 1.3\% shares respectively (IFSB, 2019).

\section{The Genesis of Islamic banking in Ethiopia}

Ethiopia is a country with a substantial number of Muslim populations. According to the central statistic Authority of Ethiopia census 2007(CSA, 2007), Muslims account for $34 \%$ of the total population of Ethiopia. Unfortunately, Ethiopia is a country with very law bank service penetration. The Global Findex Database 2017 states that only $34.8 \%$ of adults aged more than 15 years have a bank account. This means $65.2 \%$ of adults are not accessing basic financial services in Ethiopia (Demirgüç-Kunt, et al., 2018). The unavailability of alternative shariacompliant financial products and services in Ethiopia played a significant role in inducing financial exclusion which in turn resulted in law bank usage in Ethiopia (Hailu, Kapusuzoglu, \& Ceylan, 2019).

There was no legal framework that permits the establishment of Islamic finance in Ethiopia before 2008. As a result, Ethiopian Muslims were demanding for years, the establishment of Interest free banking service. In 2007, Ethiopian Muslims Diaspora community representatives presented different questions for the late Prime Minister Meles Zenawi. The request for permission to establish Islamic banking in Ethiopia was among these questions (Feyissa, 2012). Furthermore, in 2008, a group of entrepreneurs and community leaders with the aspiration to establish an Interest free bank named "Zem-zem bank" presented the benefit and importance of Islamic finance for the late Prime Minister Meles Zenawi. After the meeting, the prime minister directed the National Bank of Ethiopia (NBE) to issue a new proclamation that permitted the establishment of Interest-free finance in Ethiopia (Al-Hashimi, 2012). Consequently, NBE issued a Proclamation concerning Banking Business: Proclamation No: 592/2008. In this Proclamation, Article 22, Sub-article 2 states “The National Bank may issue a directive to regulate banking businesses related to non-interest-bearing deposit mobilization 
and fund utilization." This was the first practical measures taken by NBE to adopt the practice of Islamic finance in Ethiopia.

Based on Proclamation No: 592/2008: Article 22, Sub-article 2, all conventional banks in Ethiopia started to accept interest-free deposits from those customers who are interested in interest-free banking service. A substantial amount of money is deposited in all conventional banks, with depositor aiming no more than a safeguard. Currently from the 18 conventional banks, 10 of them are providing IFB service through window and On the other hand, Zamzam bank organizers started selling shares in December 2010 to establish a full-fledged Interest free bank. Though the minimum paid-up capital to establish a bank was 75 million Ethiopian Birr (2.7 Million USD), Zamzam bank was able to collect 137 million Birr (4.9 million USD), almost twice as much the minimum paid-up capital, within four months from more than 6800 subscribers (Zam-zam Bank Under formation, 2012). Nevertheless, a new directive was issued by NBE that undermined the hope of establishing full-fledged Islamic banking in Ethiopia. This directive is called "Directives to Authorize the Business of interest-Free Banking No. SBB/ 51/2011". According to this directive, only established conventional banks can offer interestfree banking merely on window modes. Article 2: sub-article 3 defines an interest-free banking window as a unit within a conventional bank exclusively offering interest-free banking services". No explanation was given from the government as to why this directive is decreed outlawing the former one. Following this directive, Commercial Bank of Ethiopia (CBE) and Oromia International Bank (OIB) got an endorsement from the NBE to offer interest-free banking window services in 2013. Currently, almost all conventional banks in Ethiopia are offering interest-free banking window.

Even though the NBE closed the door to establishing full-fledged Interest free bank in Ethiopia, Muslim communities did not give up from demanding it. After a 7 years exclusive interest-free banking window practice in Ethiopia, the NBE issued a new proclamation that permits the establishment of full-fledged interest-free banking in Ethiopia in May 2019. The proclamation is known as proclamation No: 1159/2019 to approve for the amendment of banking business proclamation. In this proclamation article 59 devoted to "interest-free bank" and sub-article 1 states that:

"Without prejudice to the requirements of specified under the provisions of the proclamation, the National Bank may issue a Directive to prescribe additional conditions of licensing, supervision and requirements to establish Interest-Free Bank. For this sub-article, Interest-Free Bank means a company licensed by National Bank to undertake only interest-free banking business".

Proclamation No: 1159/2019 made the dream of establishing a full-fledged interest-free bank in Ethiopia real. The proclamation was issued after the current Prime Minister Dr, Abiy Ahmed promised to permit the establishment of full-fledged interest-free banking on his speech during the Ramadan Iftar (fast-breaking) program organized by the Ethiopian Islamic 
Affairs Supreme Council (EIASC) at Millennium Hall on May 22, 2019 (Getachew \& Kedir, 2019).

Following the prime ministers promise and the declaration of proclamation No: 1159/2019, several share companies queued requesting a license from NBE to provide full-fledged interest-free banking services in Ethiopia. According to Tadesse (2019), until July 2019, four banks named Zem-zem, Hijira, Nejashi and Zad were in the stage of establishment, while another four share companies are in process to get a license from NBE.

Even though the permission of establishing full-fledged interest-free banking in Ethiopia is a prodigious opportunity for those who were demanding for several years, challenges like the unavailability of a conducive legal framework, the shortage of skilled professionals, hostile attitudes towards Islamic bank ...etc may affect the performance of interest-free banking in Ethiopia.

The purpose of this study is investigating the potential opportunities and challenges of fullfledged interest-free banking in Ethiopia in line of the new enacted directive No. SBB/72/2019. Accordingly, this study tries to answer for the following two main questions:

- What are the potential opportunities for Islamic Banking in Ethiopia?

- What are the impending challenges for Islamic banking in Ethiopia?

The findings of this study provide significant implications for policy makers who are responsible in issuing banking business regulation and for investors who are interested to invest in Islamic Banking sector. Further, this study will contribute to the literature on Islamic banking in Ethiopia as the newness of the sector and unavailability of adequate literatures. Finally, it will encourage researchers to do more investigations and academic studies on this area.

The rest of the paper is set out as follows: In the next section, we analyzed related literatures on the topic. In Section 4, we describe the methodology applied to explore prospects and challenges of Islamic banking in Ethiopia. Analyses of the collected data are presented in Section 5. Summary and conclusions are presented in section 6 and further research directions are presented in the final section.

\section{Literature Review}

There are myriads of studies conducted to identify the potential challenges which affect the performance of Islamic finance. In this section, the common challenges of Islamic finance and specific challenges at the country level are summarized. Iqbal, Ahmad \& Khan (1998) noted that the challenges facing Islamic banking are lack of appropriate institutional structure, competition with conventional banks, lack of innovation of new sharia-compliant financial instruments, lack of scholars with dual specialization with modern finance and Islamic sharia, the absence of institutions providing training, teaching and research on Islamic finance and 
the unavailability of proper legal framework, policies and procedures to apply Islamic banking products.

Iqbal \& Mirakhor (1999) illustrated the challenges facing Islamic finance by categorizing it into two groups such as financial engineering and operational challenges. Among the financial engineering problems that affect the implementation of Islamic finance principles for additional innovation is the need of special commitment to implement the financial engineering practices to Islamic banking regarding whether compliant with sharia principles or not. The absence of legal and institutional frameworks that enhance the application of Islamic finance principles, the deficiency of an equity-based benchmark or reference rate for asset pricing or evaluating projects and lack of standards to introduce new sharia-compliant products are the operational challenges they elaborated.

Karbhari, Naser \& Shahin (2004) stated that lack of homogeny, absence of regulation, capital and liquidity requirements, tax distinction, lack of adequate financial instruments, the requirement of special accounting practices, the absence of risk management tools, lack of professionals in Islamic finance and competition with conventional banks are the challenges faced during the application of Islamic finance in the west. Uppal \& Mangla (2014) also identified global challenges of Islamic banking such as the increasing of competition within the banking industry; operational challenges including providing products and services at competitive cost and risk management; and the conflicts of interest between regulatory bodies and the sharia scholars regarding the application of services and products.

Zamil \& Aiza (2014) empirically investigated the problems and challenges facing Islamic banking in Malaysia. They identified challenges such as the influence of window banking system, lack of encouragement from the regulatory body related to sharia-compliant products and services, providing of products and services which are not compliant with sharia principles, lack of proper operation and management, lack of expertise in human resource, lack of responsibility, and lack of appropriate accounting and auditing practice. Tabash (2017) investigated the critical challenges affecting Islamic banking in India using the analytic hierarchy process. His finding indicated that the absence of proper regulatory framework, lack of experts in Islamic banking, lack of awareness regarding Islamic banking, absence of standard-setting and lack of collaboration and harmonization between Islamic banks are the main challenges facing Islamic banks in India.

Studies conducted to assess the challenges of interest-free window banking practice in Ethiopia are reviewed as follows. Muhumed (2012), Ali (2016), Tsion (2017), Getachew (2018), Jemal (2018), Bati (2018) and Wondwosen (2018) identified challenges facing the interest-free banking window practice in Ethiopia such as lack of conducive legal framework and lack of cooperation from government, absence of Shariah advisor, lack of skilled human resource, lack of awareness of clients, unavailability of effective supervision by NBE, negative perception regarding interest-free finance resulted from unjust association with religious extremism, absence of equity markets, lack of collaboration between interest-free window providers, lack 
of set-up appropriate for Interest-free banking business, insufficient marketing and advertising, double taxation and the absence of standardization.

Abate (2016) assessed the Ethiopian interest-free banking regulation in light of global Islamic finance standards and concluded that using as a legal frame work the existing single and sketchy proclamation No. SBB/ 51/2011 to govern interest-free banking service will be a challenge. He recommended NBE to develop a comprehensive directive for a smooth application of interest-free banking system. Sefiani (2014) states that the absence of a suitable legal framework, the lack of skilled Islamic banking experts and inadequate awareness about Islamic finance products are the challenges of Interest-free banking practice in Ethiopia. Sefiani recommended the NBE to revise the proclamation No. SBB/ 51/2011 in order to resolve legal problems affecting the interest-free banks such as participation in non-banking business, value-added tax on merchandises and double taxation. Aman (2019) descriptively analyzed the expansion and financial performance of IFB windows in Ethiopia. His findings indicate that IFB windows in Ethiopia were able to exponentially expand their deposit accumulation through IFB. Moreover, their financial performance expressed in terms of income and profitability is showing substantial growth.

Ahmed (2019) investigated Ethiopian interest-free banking proclamation after the enactment of Directive No. SBB/72/2019. According to Ahmed (2019), there is no difference between the proclamation No. SBB/51/2011 and Directive No. SBB/72/2019. Moreover, the legal framework of Ethiopia is not appropriate for launching full-fledged interest-free banking. Accordingly, there is a need for a conducive legal framework to practice full-fledged interest-free banking in Ethiopia.

\section{Research Methodology}

As mentioned earlier in the introduction section, four fully-fledged Interest free banks are under formation. Two of them have already raised the minimum paid-up capital required to start a bank and established board of directors. Hopefully, they will join the finance sector in a very short time. The aim of this paper is assessing the available opportunities and challenges which may affect the performances of interest-free banking business in Ethiopia. To investigate the opportunities for interest-free finance in Ethiopia, this paper will analyze secondary data gathered from diverse sources. Regarding the effectiveness of interest-free window banking, we analyzed available annual reports of banks in addition to other secondary data that can show the potential prospect of interest free banking in Ethiopia.

Although there are various challenges faced by Islamic banks, in this paper we will focus on three categories of challenges we presume to have a significant impact on the performances of Interest free banks. Accordingly, the three categories of key challenges are negative perception toward interest-free banking, legal framework challenges and shortages of experts and skilled human resources. To investigate perceptions toward interest-free finance, we analyzed the social and mainstream media reactions following Prime minister Dr, Abiy Ahmed's vow for the establishment of full-fledged interest-free banking on May 22, 2019. The potential 
challenges regarding legal frameworks are identified by thoroughly examining the banking business proclamations in light of international practices. Finally, challenges related to the shortage of experts and skilled human resources are assessed in accordance with the education system of the country, in addition to the related literature review.

\section{Analysis}

\subsection{Opportunities for Islamic banking in Ethiopia}

\subsubsection{Huge Amount of Potential Customer}

There are several potential opportunities for Interest free finance in Ethiopia. Among these opportunities, the first one is the availability of huge potential customers who have been excluded from accessing conventional finance products and services mainly due to religious reasons. The success of every business is mainly depending on the availability of potential customers who can access the products and services provided. As the basic principles of Islamic finance are originated from Sharia rules, it is expected to be Muslims are the primary customers for Interest free finance products and services. According to the World Population Review (2019) estimation, the population of Ethiopian reached 113 million and 34\% (38.5 million) out of the total population are Muslims. The availability of a substantial Muslim population is the primary potential opportunity for the expansion of Interest free finance in Ethiopia. The ever increasing number of banks providing IFB service in window and subsidiary model, and customers who have accounts in these window services is another indicator of huge amount of potential customer. In 2018 only Oromia International bank and Cooperative bank of Oromia had 248,614 and 660,000 customers of IFB respectively (Aman, 2019).

\subsubsection{High Popular Demand}

The second opportunity that encourages Interest free banking in Ethiopia is the high popular demand for it from the Muslim population manifested for a protracted period. Ethiopian Muslims were expressing their demand to interest-free finance through different ways to the government. The request of Ethiopian Muslim Diaspora representatives and the establishment journey of Zamzam Bank from 2008 to 2011 are the main events which indicate the resolute demand of Ethiopian Muslims for Interest-free finance. These events are described in the introduction section more meticulously. Concerning this point, Hailu et al (2019) surveyed 321 respondents in Addis Ababa, the capital city of Ethiopia by asking the respondents plan if fullfledged interest-free banking is allowed in Ethiopia. 64.5\% of respondents indicated that they will access the products and services and $33.6 \%$ of them expressed their interest to be a shareholder in full-fledged interest-free bank. The ever increasing number of IFB service users in the window model is additional evidence that portrays the higher demand for IFB service. Given the fact that the windows are providing limited IFB products (Aman, 2019) and the concern regarding sharia compliance of IFB window will be an adequate reason for customers to use fully-fledged banks. 


\subsubsection{Easy Deposit Mobilization and Profitability of IFB Windows}

The third opportunity that signifies the potential effectiveness of full-fledged interest-free banking in Ethiopia is the success of Interest-free banking windows in collecting huge amount of money through interest-free deposit schemes. According to Tadesse (2019), from a total of 17 state-owned and private banks in Ethiopia, 11 banks accepted the license to provide interest-free banking window services and 10 of them already launched the services. Deposits are collected mostly by three types of accounts such as Amanah (current account), Wadi'a (saving account) and Mudarabah (profit sharing account). The state-owned Commercial bank of Ethiopia (CBE) that dominated the banking sector in Ethiopia also dominated the interestfree banking window services. Tadesse (2019) noted that the total deposit collected by all commercial banks providing interest-free window services at the end of May 2019 was 40 Billion Ethiopian Birr (1.5 billion USD) and CBE has a 66\% share from this deposit. Cooperative Bank of Oromia (CBO), Oromia International Bank (OIB) and Awash Bank (AB) also has a substantial share from the total deposit collected throughout the country. Taye (2019) states that, the total amount of deposit collected by all interest-free banking window service provider commercial banks was 20 billion ETB (715 million USD) before 2 years and it reached now 40 billion ETB (1.5 billion USD) . Thus, deposit mobilization in interest-free window banking in Ethiopia shows a $100 \%$ increase within just 2 years.

Table 1: Deposit collected and Income generated by CBE, CBO and OIB from IFB window

\begin{tabular}{|c|c|c|c|c|c|c|}
\hline \multirow[t]{2}{*}{ BANK } & \multicolumn{2}{|c|}{ IFBW deposit in ETB* } & \multirow{2}{*}{$\begin{array}{l}\text { Growth in } \\
\text { Deposit }\end{array}$} & \multicolumn{2}{|c|}{ IFBW profit in ETB } & \multirow{2}{*}{$\begin{array}{l}\text { Growth } \\
\text { in } \%\end{array}$} \\
\hline & 2018 & 2019 & & 2018 & 2019 & \\
\hline $\mathrm{CBE}^{* *}$ & 14 billion & 25 billion & $78.57 \%$ & - & - & - \\
\hline $\mathrm{CBO}^{* * *}$ & 2.2 billion & 5 billion & $125.23 \%$ & 20.36 million & 77.58 million & $281 \%$ \\
\hline $\mathrm{OIB}^{* * * *}$ & 3 billion & 4.16 billion & $38 \%$ & 223 million & 244 million & $9 \%$ \\
\hline $\begin{array}{l}\text { Sources: } \\
* \text { USD/ET } \\
* * 14 \text { billi } \\
\text { *** Collec } \\
\text { *** Colle }\end{array}$ & $\begin{array}{l}\mathrm{B} \text { rate is } 1 / 2 \\
\text { on per Febru } \\
\text { ted from } \mathrm{CB} \\
\text { ted from } \mathrm{O}\end{array}$ & $\begin{array}{l}\text { ary } 8,2019 \text { an } \\
\text { O } 2018 / 2019 \text { a } \\
\text { B } 2018 / 2019 \text { a }\end{array}$ & $\begin{array}{l}25 \text { billion per } \\
\text { nual report } \\
\text { nual report }\end{array}$ & 13 October 20 & & \\
\hline
\end{tabular}

The interest-free deposit collected and the income generated from interest-free services in 2018 and 2019 by CBE, CBO and OIB are summarized in Table 1. There is a significant growth in the amount of deposit collected and the income generated from IFB window services. Despite the economies of scale advantage conventional banks enjoy when providing IFB window service, the tremendous growth in deposit mobilization and higher profit margin they earned by providing a restrictive IFB window service indicate the potential for full-fledged interestfree banks to be profitable by providing a wide range of Sharia Compliant products and services. Aman (2019) analyzed the performance of IFB windows. His findings indicate an incredible growth of profitability. Ahmed (2019) investigated the expansion and performance 
in deposit mobilization and financing of interest-free banking window. He concludes that the emergence of full-fledged interest-free finance in Ethiopia has a potential opportunity.

To sum up, the availability of huge potential customers who could not access conventional finance products and services mainly due to religious reasons, the high demands of Muslims for full-fledged interest-free banking, the success of Interest-free banking window providers in collecting a significant amount of interest-free deposit through a restricted services, and success of under formation full-fledged interest-free banks in collection of paid capital by selling shares to the public within a short period are the golden opportunities for Interest free finance in Ethiopia.

\subsection{Challenges for Fully Fledged Interest Free Banking in Ethiopia}

\subsubsection{Negative Perception towards Interest-free Banking}

After a protracted struggle and determined demand, Ethiopian Muslims heard the good news through the promise of PM Dr Abiy in May 2019, at an IFTAR event organized by Ethiopian Islamic Affairs Council, to allow the establishment of fully-fledged Interest free bank in Ethiopia. Nevertheless, the news is not welcomed by all. As mentioned earlier in the methodology section, we employ content analysis to measure the perception towards Islamic bank. Hence, we assessed the public response under the news that disclosed the PM's vow to allow the establishment of an Interest free bank. First, we examined comments given under news published on a Face book page of Fana Broadcasting Corporate (FBC), a pro-government mainstream media, regarding the establishment of Interest free bank in Ethiopia.

The post has more than 8 Thousand engagements of which 873 are comments. Most of the comments are not related to the news. However, a substantial amount of comments related to the news reflected negative connotations. More than 40 commenter opposed governments vow to allow the establishment of a full-fledged Interest free bank. The commentaries mentioned various reasons for their opposition. In general, the opposing comments fall into four categories. The first group of comments related to the establishment of fully-fledged banking with religious radicalism. They expressed their concern that the banks will empower extremists. The second group formed their argument on the notion of secularism. They opined their opposition stating that, allowing Interest free bank is against the principles of secularism. The third group of commenter's claims that allowing the establishment of Islamic banks will push Christian Ethiopians to demand a Christian bank, which may lead to a division based on a religious fault line. The last group of comments stated the adequacy of having interest-free windows under conventional banks. It is clear that these negative perceptions are not peculiar to Ethiopia (FBC (2019, May 22).

Another implication of the public reaction is a live radio discussion on local Fm named Sheger FM 102.1 broadcasted on July 11, 2019. In this live radio discussion around 6 attendants called and participated, of which four callers skeptic about the establishment of fully-fledged Interest free were banking in Ethiopia. They raised the common biased claim of connecting Islamic 
banking with religious extremism, beside the spurious concern that it will create a religious fault line in addition to the already existing ethnic division (Sheger FM., 2019, July 11).

The negative perception is not confined to the Non-Muslim community only. Significant numbers of Muslim Ethiopians have lack of awareness towards Interest free banking and the service being rendered (Safiani, 2009). A study conducted by Elias Endale (2015) for partial fulfillment of master's program titled "Customers` Perception towards Interest-Free Banking Products and Services: In Selected Branches of Commercial Bank of Ethiopia" also states the negative perception towards Interest free banking. Both Safiani's and Endale's findings converge with what we have stated above inferring from public reaction express on social and mainstream media.

Besides the reaction of the public following the announcement of the government to allow the establishment of fully-fledged Interest free banks, in the following section, we will examine the perception by analyzing Five mainstream media reports on the issue. The media's examined are BBC Amharic, DW Amharic, ESAT TV, Gion Megazine and Addis Maleda.

DW Amharic welcomed Governments decision to allow the establishments of fully-fledged interest free banks in their article published on July 17, 2019. Besides, they interviewed organizers of two under formation fully-fledged banks and try to shed light on common misconceptions regarding Interest free banking. DW Amharic is one of the few media's which positively portrayed the relevance of having fully-fledged Interest free bank. BBC Amharic is another media, which gave a wide coverage for the topic. Though they neither explicitly welcomed nor opposed the government decision, their report is tantamount to a welcoming one. BBC Amharic, in their report on July 9, 2019, interviewed a scholar of Islamic finance. Though most of the questions raised by the journalist have a stereotypic flavor, their effort to put off misconceptions is plausible.

An interview with Islamic finance scholar name Dr Abdu Seid conducted by ESAT TV on may 27, 2019 is also analyzed for this study. The journalist echoed his concern like IFB is only for Muslims; IFB is charitable company and the difficulty of controlling IFB. However his concerns are mere reflections of his wrong perception.

On the other side, reports on Gion magazine and Addis media newspaper opposed the government's decision to allow fully-fledged interest free bank. An article published on Gion Magazine in June 2019 by a famous economic commentator named Kibur Genna, reflects their discontent and misconceptions they have regarding Islamic finance. Kibur Genna wrote on Gion magazine that, the government has made a fatal mistake by allowing the establishment of Interest free bank. He based his argument on spurious cases. He claimed that Interest free bank will be another divisive factor in Ethiopian politics, though he failed to substantiate his claim. He further argued that Islamic banks are established to serve merely the Muslim community, which by no means is acceptable (Genna, 2019, May).

Another print media which is examined for this study is Addis Maleda, a weekly newspaper. A columnist of Addis Maleda named Yayesew Shimelis wrote an article titled the "politics of 
Islamic banking". In his article Yayesew audaciously claimed that there are international extremist groups behind Ethiopia Muslims demand to have a fully-fledged Islamic bank. He argued that the service provided in window model by conventional banks is more than enough. For him, Muslim countries are an eternal enemy of Ethiopia. Hence allowing for the establishment of Islamic bank is allowing Muslim countries, specifically Gulf countries, to have a huge stake in our economy voraciously. This economic stake will obviously impact our politics and jeopardize our interest. He additionally argued that allowing Islamic bank will be both a source and a means of transfer of funds for religious extremists which will bring a security threat for the country (Shimelis, 2019, June).

\subsubsection{Legal Framework Challenges}

Different types of approaches have been applied by countries to accommodate the Interest free banking system in their legal framework. Song \& Oosthuizen (2014) identified four types of adaptation practice in the legal framework such as similar combined regulatory framework without reference to conventional or Islamic banks, similar combined regulatory framework by referencing directives applying either to Islamic or conventional banks, distinct legal framework for Islamic banks and mixed approach with single regulatory framework separate guidelines for conventional and Islamic banks. The approaches of Ethiopia to accommodate Interest free banking in its legal framework seems like the second approach, i.e. similar combined regulatory framework by referencing directives applying either to Islamic or conventional banks.

Proclamation No:1159/2019, a proclamation to approve the amendment of banking business proclamation states that "Without prejudice to the requirements of specified under the provisions of the proclamation, the National Bank may issue a Directive to prescribe additional conditions of licensing, supervision and requirements to establish Interest-Free Bank". This indicates that without prejudice to the regulatory framework enacted to conventional banks, further guidance for Islamic banks will decree by NBE. One of the basic questions should be asked at this point is whether Islamic banking principles are applicable under the guidelines prescribed in the banking business proclamations which ratified by NBE or note. Considering proclamations related to banking business activities listed under Proclamation No. 592/2008 and amendment Proclamation No:1159/2019, the special activities performed by Islamic banks are not listed in the proclamation.

One of the basic legal framework challenges for Islamic banks is the directive related to the limitation on Investment of banks stated in Directive No. SBB/60/2015. Under this directive article 4 (4) states "A bank may hold up to $10 \%$ equity shares in a single non-banking business other than insurance business" and article 4 (6) also indicated that "A bank's aggregate equity investment in all non-bank business, including insurance companies, shall not exceed $10 \%$ of its net worth". There is no clarity whether these articles are applied for Islamic banks or not. If it is applicable, Islamic banking products like Mushareka and Mudareba cannot be practiced in these legal frameworks since most of Islamic banking products depend on equity 
investment. Pertaining to this point, Sefiani (2014) stated that "these articles create a conflict for issuing Musharaka or a Mudaraba partnership agreement in which a bank could own up to $100 \%$ of a business/transaction at the time of the signing of the contract".

Another potential challenge for Murabaha (Cost-plus-Profit Sale) transaction which is rendered by Interest free banks is double taxation. The purpose of Murabaha is providing goods with mark-up profit instead of giving loan with interest to customers. Accordingly, the Murabaha transaction is taxed two times when the bank buys the product from suppliers and when the customer buys from the bank. If direct taxes like income tax from business (trade) activities and indirect taxes like Value Added Tax (VAT) and Turnover Tax (TOT) are enforced for Murabaha transaction, this Islamic banking product cannot be competitive and preferable by customers too.

One of the basic principles of Islamic finance is the services and products provided by Interest free banks should meet Sharia principles. So, there is a need for responsible authority who control whether products and services rendered by interest-free banks are compliant with sharia principles or not. The NBE has nothing to say neither about the controlling mechanism nor about the responsible body who controls the fulfillment of sharia principles. Consequently, there is a need to enact a directive by NBE regarding the controlling mechanism and Sharia board.

In addition to the above-mentioned challenges, NBE does not say anything about the accounting standards interest-free banks shall adopt. There are three main Islamic financial standards such as the Accounting and Auditing Organization for Islamic Financial Institutions (AAOIFI), the Islamic Financial Services Board (IFSB), and the International Islamic Financial Market (IIFM). Therefore, there is a need to adopt one of these institutions for Islamic banking practice in Ethiopia, so that consistency and uniformity prevails. In general, the exclusiveness of banking business activity, limitation on investment of banks, double taxation of Murabaha transaction, unavailability of controlling mechanism by NBE and not adopting Islamic financial standards to follow are among the legal framework challenges which affect the practice of full-fledged interest-free banking in Ethiopia.

\subsubsection{Shortages of Islamic Finance Experts}

The shortages of Islamic finance experts who have both the conventional finance and Sharia knowledge is one of the biggest challenges full-fledged Interest free banks encounter. Lack of Islamic finance experts mainly resulted from the unavailability of educational institution that provides Islamic finance courses, seminars and trainings. Islamic finance courses are not given even as a single course in the private and state-owned universities and colleges throughout the country. Interest-free banking window providers are either sending their staffs for training in foreign countries or bring experts from other countries. In terms of the cost in either case, it affects the profitability of the bank. The problem is also observable from the experience of IFB window providers Sharia advisory board recruitment. Almost all IFB window providers have organized a sharia advisory board and most of the board members in all banks are traditional 
religious teachers not Islamic finance experts. This clearly portrays the fact that, there is a remarkable shortage of skilled Islamic finance experts that can adversely affect the practice of IFB in Ethiopia.

Legal frame-work challenges and shortage of experts are not a challenge for Islamic banking in Ethiopia but also, they are a global challenge for Islamic finance Industry. Bello \& Abubakar (2014) assessed challenges may face for the introduction of Islamic banking in Nigeria. Their finding indicated that legal frame-work challenges and shortage of experts are among the main challenges identified. Karbhari et al. (2004) also stated that regulatory problems and lack of adequately qualified persons in Islamic finance are among main problems that Islamic banking faces in the UK. Karimi (2007) indicated that the need of special regulatory framework by Islamic banking is one of the most significant challenges encountering the Islamic banking industry. Further, Mohd Zamil (2014) and Halim (2011) also identified both regulatory framework challenges and lack of expertise as a major challenge for Islamic banking industry. Ahmad \& Hassan (2007) and Mzee (2016) stated that absence of a well-defined legal and controlling framework is one of the main challenges for Islamic banks.

\section{Conclusion}

The aim of this study is investigating the potential prospects and challenges of full-fledged interest-free banks in Ethiopia which are endorsed to the financial industry at the end of 2019. For this purpose, we analyzed several secondary source data such as reports, magazine, newspapers, news and previous researches. We analyzed descriptively the data related to the availability of potential customers, needs, the performance of IFB window providers and the progress of under formation full-fledged interest-free banks. The result indicated that Islamic finance has a golden opportunity in Ethiopia such as unbanked huge customers, high-level needs and the profitability of IFB window. This result converges with conclusion reached by Ahmed (2019) regarding the potential opportunities of Islamic finance in Ethiopia. In addition to Ahmed (2019), Aman (2019) also concluded that IFB has a bright future in Ethiopia.

Although Islamic finance in Ethiopia has golden opportunities mentioned above, it is anticipated that the implementation of this financial system will face many challenges. For this reason, we analyzed three anticipated challenges such as negative Perception, legal framework, lack of experts and human resources who are qualified both in conventional and Islamic finance knowledge. To investigate the perception toward Islamic finance in Ethiopia, we implemented a content analysis of social and mainstream media reaction and analysis given following Prime minister Dr. Abiy Ahmed's vow to facilitate the permission of fullfledged Islamic banking on May 22, 2019. The finding indicated that there is a negative perception towards Islamic finance in Ethiopia which is mainly resulted from common misconceptions. Therefore, there is a need to create awareness about Islamic finance in Ethiopia trough training, workshop, seminar, social and mass media campaigns.

Legal framework challenges are assessed by analyzing the legal system of Ethiopia in light of Islamic finance principles. The finding shows that the exclusiveness of banking business 
activity, limitation on investment of banks, tax system and unavailability of controlling mechanism and not referencing to one of the Islamic financial standards to follow are among the anticipated legal framework challenges which obviously affect the practice of full-fledged interest-free banking in Ethiopia. Therefore, it is recommended to the government of Ethiopia to make adjustments on the legal frameworks in a way that accommodates Islamic finance practices and enhance their performance in the financial system of the country. The challenge regarding shortages of experts and skilled human resources is analyzed considering the reality happening in the sector and this problem is identified as the main challenge for the sector in Ethiopia. Therefore, there is a need of institutions which can provide undergraduate and postgraduate programs, seminars, training, researches, etc. in the area of Islamic finance.

Future Research Direction:

It is suggested that there is a need for deep investigation regarding prospects and challenges of Islamic finance in Ethiopia. The success /failure of interest free window stage in Ethiopia within 8 years (2011-2019) need a deep investigation. Currently 4 conventional banks in Ethiopia have started providing Islamic banking services separately through subsidies. Therefore, there is a need to study the driving force for conventional banks to launch Islamic banking services by subsidiary in addition to window services. Moreover, economic role of IFB in Ethiopia can be a potential thematic area for future study. 


\section{References}

Abate, A. (2016). The Regulation and Supervision of Interest-Free Banking in Ethiopia (Unpublished Master's thesis, Addis Ababa University).

Ahmad, A. U. F., \& Hassan, M. K. (2007). Regulation and performance of Islamic banking in Bangladesh. Thunderbird International Business Review, 49(2), 251-277.

Ahmed, M. I. (2019). The Progress to Allow Fully Fledged Interest Free Banking Business in Ethiopia. European Journal of Islamic Finance, (14).

Alharbi, A. (2015). Development of the Islamic Banking System. Journal of Islamic Banking and Finance, 3(1), 12-25.

Al-Hashimi, M., A., 2012: Ethiopian Muslims and the Ahbash controversy. Retrieved January 12, 2020, from https://crescent.icit-digital.org/articles/ethiopian-muslims-and-theahbash-controversy

Ali, K. (2016). Challenges on Interest Free Banking Services: The Case of Commercial Bank of Ethiopia (Unpublished Master's thesis, Addis Ababa University).

Aman, A. (2019). Interest free window banking and finance in Ethiopia: inception to expansion. Journal of economic library.6(4), 1-14

Bati, M. (2018). Assessment of Post Implementation Challenges of Interest Free Banking Project: The Case of Commercial Bank of Ethiopia (Unpublished Master's thesis, Addis Ababa University).

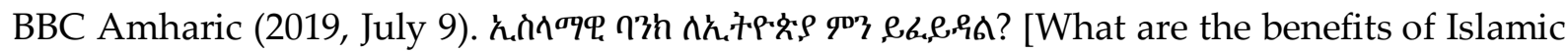
banking for Ethiopia?] Retrieved from https://www.bbc.com/amharic/news-48914948

Bello, A., \& Abubakar, M. I. (2014). Challenges and solutions to Islamic banking system in a pluralistic-secular country like Nigeria. Journal of Islamic Economics, Banking and Finance, 113(3580), 1-19.

Chachi, A. (2005). Origin and development of commercial and Islamic banking operations. Islamic Economics, 18(2).

Demirgüç-Kunt, A., Leora K., Dorothe S., Saniya A., and Jake H. 2018. The Global Findex Database 2017: Measuring Financial Inclusion and the Fintech Revolution. World Bank: Washington, DC.

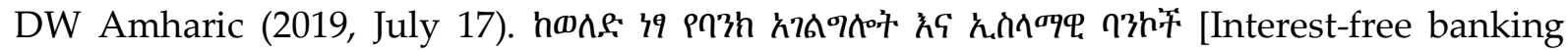
services and Islamic banks]. Retrieved from https://www.dw.com/am/

Endale, E. (2016). Customers perception Towards Interest Free Banking Products and Services: In Selected Branches of Commercial Bank of Ethiopia (Unpublished Master's thesis, St. Mary's University). 


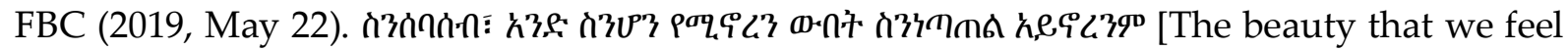
when we come together, we will not have when we are apart]. Retrieved from https://www.facebook.com/pg/fanabroadcasting/posts/?ref=page_internal

Feyissa, D. (2012). The transnational politics of the Ethiopian Muslim diaspora. Ethnic and Racial Studies, 35(11), 1893-1913.

Franzoni, S., \& Ait Allali, A. (2018). Principles of Islamic Finance and Principles of Corporate Social Responsibility: What Convergence? Sustainability, 10(3), 637.

Gait, A. H., \& Worthington, A. C. (2007). A primer on Islamic finance: Definitions, sources, principles and methods.

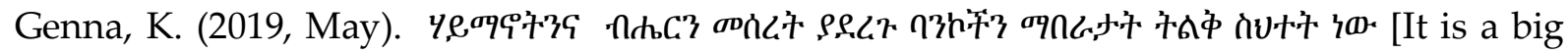

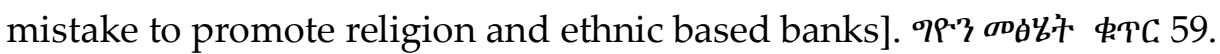

Getachew, A. \& Kedir, S. (2019, May). Ethiopian PM attends iftar with Muslim community: Abiy Ahmed promises grand mosque, interest-free banking for Muslims. Anadolu Agency. Retrieved January 12, 2020 from https://www.aa.com.tr/en/africa/ethiopianpm-attends-iftar-with-muslim-community/1484949

Getachew, Y. (2018). Assessment of Prospects and Challenges of Interest Free Banking In Ethiopia In The Case Of Commercial Bank Of Ethiopia, North Addis District (Unpublished Master's thesis, St. Mary's University).

Global Islamic Finance Report (GIFR). 2019. Islamic Finance Country Index (IFCI). Retrieved on January 12, 2020, from http://www.gifr.net/publications/gifr2019/ifci.pdf

Hailu, S. M., Kapusuzoglu, A., \& Ceylan, N. B. (2019). The Role of Islamic Financial Product Innovation in Reduction of Financial Exclusion in Ethiopia. In Handbook of Research on Managerial Thinking in Global Business Economics (pp. 426-446). IGI Global.

Halim, M. A. B. A. (2011). Enhansing the Effectiveness of Legal Infrastructure: A Study on Legal Issues and Other Challenges of Islamic Banking and Finance in Malaysia, paper from 8th International Conference on Islamic Economics and Finance. Center for Islamic Economics and Finance, Qatar Faculty of Islamic Studies, Qatar Foundation, 19-21.

Hussain, M. M., \& Pasha, A. T. (2011). Conceptual and operational differences between general takaful and conventional insurance. Australian Journal of Business and Management Research, 1(8), 23-28.

Iqbal, M., Aḥmad, A., \& Khan, T. (1998). Challenges facing Islamic banking (Vol. 1). Jeddah: Islamic Research and Training Institute.

Iqbal, Z., \& Mirakhor, A. (1999). Progress and challenges of Islamic banking. Thunderbird International Business Review, 41(4-5), 381-405.

Islamic Financial Servcies Board (IFSB). 2019. Islamic Financial Services Industry Stability Report. Kuala Lumpur, Malaysia, July. 
Jemal, N. (2018). Practices and Challenges of Interest Free Banking Windows of Commercial Banks in Ethiopia (Unpublished Master's thesis, AAU).

Karbhari, Y., Naser, K., \& Shahin, Z. (2004). Problems and challenges facing the Islamic banking system in the west: The case of the UK. Thunderbird International Business Review, 46(5), 521-543.

Karbhari, Y., Naser, K., \& Shahin, Z. (2004). Problems and challenges facing the Islamic banking system in the west: The case of the UK. Thunderbird International Business Review, 46(5), 521-543.

Karimi, A. J. (2007). Challenges facing Islamic banks. Dawn Media Group.

Mohamad, M. T., Abdullah, M. Y., Mohamad, M. A., \& Abidin, U. Z. A. A. Z. (2013). The historical development of modern Islamic banking: A study in South-east Asia countries. African Jornal of Business and Mnagement.

Mohd Zamil, N. A. (2014). An empirical investigation into the problems and challenges facing Islamic banking in Malaysia (Doctoral dissertation, Cardiff University).

Mollah, S., \& UDDIN, M. H. (2013). How Does an Islamic Microfinance Model Play the Key Role in Poverty Alleviation? Contemporary Islamic finance: Innovations, Applications, and Best Practices, 614, 245.

Muhumed, M. (2012). Islamic Banking: Prospects, Opportunities and Challenges in Ethiopia (Unpublished Master's thesis, Addis Ababa University).

Mzee, M. M. (2016). The Legislative Challenges of Islamic Banking in Tanzania. JL Pol'y \& Globalization, 45, 131.

Sefiani, Z., (2014). Policy Analysis on Ethiopia Interest Free Banking (IFB) Directive. Prepared for Mercy Corps.

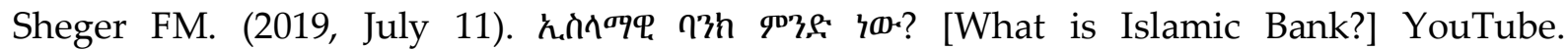
https://www.youtube.com/watch?v=3BjxBFgguco\&t=1157s

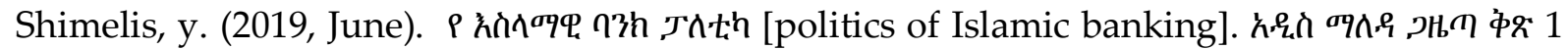
\$.TC 3.

Song, M. I., \& Oosthuizen, C. (2014). Islamic banking regulation and supervision: Survey results and challenges (No. 14-220). International Monetary Fund.

Tabash, M. I. (2017). Critical challenges affecting Islamic banking growth in India using Analytical Hierarchy Process (AHP). Banks and Bank Systems, 12(3), 27.

Tadesse, F, (2019, July). Central Bank Relaxes Interest-free Banking Rules. Fortune News. Retrieved January 12, 2020 from https://addisfortune.news/central-bank-relaxesinterest-free-banking-rules/ 
Tsion, S. (2017). Challenges and opportunities of interest free banking in Ethiopia (Unpublished Master's thesis, Addis Ababa University).

Uppal, J. Y., \& Mangla, I. U. (2014). Islamic banking and finance revisited after forty years: Some global challenges. Journal of Finance, 16, 36-51.

Warde, I. (2000). Islamic finance in the global economy. Edinburgh University Press.

Wondwosen, T. (2018). operational challenges and opportunities of interest free banking in Ethiopia (Unpublished Master's thesis, Addis Ababa University).

Zaher, T. S., \& Kabir Hassan, M. (2001). A comparative literature survey of Islamic finance and banking. Financial Markets, Institutions \& Instruments, 10(4), 155-199.

Zamil, M., \& Aiza, N. (2014). An empirical investigation into the problems and challenges facing Islamic banking in Malaysia (Doctoral dissertation, Cardiff University).

Zamzam Bank (2012). PH'PH work report). Addis Ababa. 